\title{
MENERAPKAN ETIKA NILAI MAX SCHELER DALAM PERKULIAHAN PENDIDIKAN PANCASILA UNTUK MEMBANGUN KESADARAN MORAL MAHASISWA
}

\section{Paulus Wahana}

Program Studi Pendidikan Guru Sekolah Dasar JIP, FKIP, Universitas

Sanata Dharma

Email: paulus_wahana@yahoo.com

\section{Abstrak}

Lembaga Perguruan Tinggi, selain mengembangkan kemampuan akademis juga memberikan matakuliah yang diharapkan dapat membangun kepribadian mahasiswa secara utuh. Matakuliah Pendidikan Pancasila, sebagai salah satu matakuliah pengembangan kepribadian, diharapkan dapat membangun kesadaran moral mahasiswa untuk mewujudkan kehidupan yang bernilai tinggi, yaitu sesuai dengan nilai-nilai luhur Pancasila. Max Scheler merupakan tokoh filsafat moral, yang menawarkan etika nilai material; menawarkan nilai sebagai landasan pertimbangan bagi tindakan manusia. Menurut pemahaman Max Scheler, dasar tindakan moral manusia diharapkan di satu pihak tidak hanya berhenti pada kesadaran untuk mencari kenikmatan atau kesenangan pribadi belaka (hedonis), dan di lain pihak juga tidak hanya berhenti pada kesadaran mentaati perintah untuk menjalankan kewajiban saja (deontologis), melainkan didasari oleh kesadaran akan kewajiban melakukan tindakan moral untuk mewujudkan nilai positif dan nilai yang lebih luhur dalam kehidupan manusia. Tulisan ini bertujuan menjelaskan penerapan Etika Nilai Max Scheler sebagai landasan bagi perkuliahan Pendidikan Pancasila untuk membangun kesadaran moral mahasiswa. Kesadaran moral mahasiswa diharapkan tidak hanya didasarkan pada kesadaran moral untuk mencari kenikmatan atau kesenangan pribadi belaka, dan tidak hanya didasarkan pada ketaatan (buta) pada aturan atau lembaga, melainkan kesadaran akan adanya kewajiban moral untuk mewujudkan kehidupan yang bernilai positif dan bernilai luhur, yang tidak lain adalah nilai-nilailuhur Pancasila.

Kata kunci:etika nilai, deontologis, teleologis, kesadaran moral, kewajiban moral.

\section{Abstract}

The universities, not only can develop the academic skill, also give lectures that 
are able to build the students' characters in complete. Pancasila Education, one of the subjects of character building, is hoped to be able to build the students' moral consciousness to create a high qualified life that is in accordance with Pancasila. Max Scheler is a moral philosopher who offers the material valueethic; offers the values as the basis thought for human action. According to Max Scheler's thought, the basic moral action of human beings hopefully does not stop at the consciousness to seek personal enjoyment (hedonist), and at the consciousness to obey the rules and do the obligations (deontologist), but do moral action based on their consciousness to create positive, high and objective values in human life. This piece of writing is aimed to explain the application of the Max Scheler's value-ethic as a base for Pancasila Education lecture to build students' moral consciousness. The students' moral consciousness is not only based on the moral consciousness to seek personal enjoyment and the obedience to regulations or institutions, but also the consciousness of the existence of a moral obligation to create positive, high and objective values in human life i.e. the high values of Pancasila.

Keywords: value-ethic, deontologist, teleologist, moral consciousness, moral obligation.

\section{PENDAHULUAN}

Mahasiswa sebagai warga masyarakat ilmiah (civitas academica) diharapkan dapat menjadi generasi penerus bangsa yang dapat berperanan dan bertanggung jawab membangun kehidupan bangsa menjadi semakin bermartabat. Mereka diharapkan memiliki kesadaran akan dirinya sebagai manusia yang merupakan makhluk bermartabat luhur di antara makhluk-makhluk lainnya. Selain makhluk jasmaniah, manusia juga merupakan makhluk rohaniah, yang memiliki kelebihan daya-daya rohaniah, yaitu: daya cipta, daya rasa, dan daya karsa. Manusia diharapkan mampu mengembangkan daya rohaniahnya tersebut, sehingga manusia tidak menjadi korban keadaan, dan tidak bersifat reaktif terhadap keadaan, melainkan mampu berperanan sebagai subyek yang mampu menyadari diri dalam menghadapi keadaan, dan bersifat pro-aktif, mampu merasakan, memikirkan, mempertimbangkan, dan akhirnya menghasilkan keputusan sesuai dengan kehendaknya untuk ditindaklanjuti dalam menghadapi keadaan serta masalah kehidupan 
dalam mewujudkan kehidupan yang bernilai. Dengan demikian manusia dapat menguasai segala hal di alam semesta ini, dan mampu membuat kemajuan yang berarti dari generasi ke generasi berikutnya (Covey, 1989: 66-77).

Menurut Covey, orang harus memulai dengan akhir dalam pemikirannya. Ini berarti pada saat manusia mulai berpikir, ternyata pemikirannya justru diawali atau didasari oleh tujuan yang pada akhirnya akan dicapai (Covey, 1989: 97-99). Masalah dasar hidup manusia justru terletak pada kesadaran akan tujuan yang perlu diwujudkan berdasar keadaan sekarangnya, yaitu kualitas-kualitas yang dirasakan paling baik untuk diwujudkan. Pemikiran memiliki peranan untuk memperoleh kejelasan tentang jalan yang perlu ditempuh, rambu-rambu yang ditemukan, berbagai rintangan yang perlu dihadapi, sarana yang digunakan, serta cara-cara dan tindakan yang dilakukan untuk mewujudkan tujuan yang sudah ditentukan tersebut. Sedangkan arah-tujuan yang sebaiknya dan seharusnya diusahakan ditentukan oleh pilihan hati nurani yang terpanggil pada nilai/kualitas atau yang baik untuk diwujudkan.

Filsafat Moral atau Etika merupakan pemikiran kritis untuk menanyakan tentang tindakan baik yang wajib diwujudkan dan tindakan jahat yang wajib dihindari. Sebagai pemikiran kritis, Etika tentu saja tidak hanya memuat daftar tentang tindakan-tindakan yang wajib dilakukan dan tindakan-tindakan yang wajib dihindari, serta tidak berhenti pada pengetahuan tentang norma-norma yang wajib ditaati, melainkan perlu mengetahui lebih mendasar tentang alasan suatu tindakan dinyatakan baik yang wajib dilakukan, dan alasan suatu tindakan dinyatakan jahat yang wajib dihindari (Bertens, 2013: 18-22). Berdasar Etika Deontologis (misal Etika Wahyu, etika peraturan), jawabannya adalah karena hal tersebut telah ditentukan dalam wahyu atau peraturan. Suatu baik dilakukan, karena wajib dilakukan; dan suatu dikatakan jahat, karena wajib dihindari atau dilarang. Namun bila mengikuti pemikiran Covey, tindakan hanya merupakan langkah yang dilakukan untuk mewujudkan tujuan, sehingga sebenarnya tujuanlah yang semestinya menentukan baik atau jahatnya tindakan. Hal ini sesuai de- 
ngan Etika Teleologis (Etika Hedonisme, Etika Eudaimonisme), menyatakan bahwa baik atau jahatnya tindakan didasarkan pada hubungannya dengan tujuan yang akan diusahakan (misalnya: kenikmatan). Namun masalahnya apa yang sebaiknya untuk menjadi tujuan yang wajib diusahakan, tentu saja jawabannya dapat bermacam-macam, berbeda-beda, tergantung subyek pelaku bersangkutan, sehingga bersifat relatif.

Namun Etika Nilai Max Scheler mampu menampung atau mengakomodasi adanya berbagai perbedaan dari paham etika teleologis tersebut di atas, karena Max Scheler memiliki pemahaman nilai yang bersikap obyektif, mendasar, serta dapat mencakup segala nilai seluruh unsur dan aspek kehidupan manusia. Nilai yang diperkenalkan Max Scheler bukanlah nilai yang bersifat subyektif (tergantung pada subyek bersangkutan), tidak yang bersifat relatif (tergantung situasi dan kondisi hal yang bernilai), melainkan bersifat obyektif, sebagai kualitas yang tidak ditentukan subyek maupun lingkungan terwujudnya nilai tersebut (Frondizi, 1971: 100; Scheler, 1973: 18-20). Nilai tidaklah terbatas pada salah satu unsur saja, misalnya kenikmatan belaka yang bersifat empiris dan hedonis, melainkan merupakan kualitas kehidupan yang mencakup unsur-unsur dan aspek-aspek yang luas dalam kehidupan manusia, misalnya: unsur jasmaniah, unsur rohaniah, aspek sosial, aspek religius. Dengan demikian dalam tindakan moral, orang tidak hanya berhenti mencari kenikmatan belaka (hedonis), dan tidak berhenti pada perintah untuk menjalankan kewajiban saja (deontologis); melainkan kewajiban melakukan tindakan moral untuk mewujudkan nilai-nilai dalam arti luas dan obyektif, yaitu nilai-nilai positif dan luhur sebagai tujuannya (teleologis).

Dalam rangka membangun pribadi mahasiswa yang mampu berperanan dan bertanggung jawab dalam kehidupan masyarakat, Lembaga Perguruan Tinggi memiliki tugas mempersiapkan serta mendampingi mereka dalam kegiatan pendidikan. Selain dibekali kemampuan dan kecerdasan akademis, diharapkan mahasiswa memiliki kesadaran moral untuk bertanggung jawab serta memiliki kepekaan hati nurani untuk mampu memilih tindakan-tindakan yang bernilai bagi kehidup- 
an manusia. Selain mata kuliah yang dapat mengembangkan kemampuan akademis mahasiswa, Lembaga Perguruan Tinggi juga memberikan mata kuliah dasar bagi pengembangan kepribadian yang diharapkan dapat membangun kepribadian mahasiswa secara utuh, yang meliputi aspek religiusitas, intelektualitas, individualitas, sosialitas, dan moralitas.

Adanya Pendidikan Pancasila di Perguruan Tinggi dimaksudkan bukan hanya sekedar untuk memberikan informasi dan pengertian tentang berbagai peristiwa historis, berbagai norma serta lembaga yang perlu diketahui dan dipatuhi, melainkan diharapkan dapat meningkatkan kesadaran moral mahasiswa akan arah-tujuan hidup manusia serta langkah-langkah tindakan yang perlu diambil agar dapat mewujudkan kehidupan moral yang bernilai/berkualitas dan dapat dipertanggungjawabkan. Dasar Etika yang ditawarkan pada Pendidikan Pancasila dalam tulisan ini bukan yang bersifat deontologis, yang didasarkan pada kewajiban moral, dan juga tidak sekedar berdasarkan nilai kenikmatan (hedonis), melainkan perkuliahan moral yang bersifat teleologis, yang didasarkan pada nilai objektif, yang menjadi arah-tujuan bagi kehidupan moral yang berkualitas dan dapat dipertanggungjawabkan, yaitu nilai-nilai positif dan nilai-nilai luhur Pancasila.

Tulisan ini bertujuan untuk dapat menjelaskan penerapan Etika Nilai Max Scheler sebagai landasan pemahaman bagi Pendidikan Pancasila untuk meningkatkan kesadaran moral mahasiswa. Berdasarkan latar belakang masalah serta tujuan tersebut di atas, kiranya dapat disebutkan beberapa hal yang perlu dipaparkan dalam tulisan ini: a) Bagaimana gambaran moralitas dan kecenderungan arah perkembangan kesadaran moral manusia; b) Bagaimana gambaran Etika Nilai Max Scheler yang dapat mendasari bagi perkembangan kesadaran moral manusia secara maksimal; c) Bagaimana gambaran penerapan Etika Nilai Max Scheler sebagai dasar pemahaman dalam Pendidikan Pancasila untuk membangun kesadaran moral mahasiswa yang dapat dipertanggungjawabkan. 


\section{KESADARAN MORAL MANUSIA}

Di antara makhluk-makhluk yang ada di muka bumi ini, manusia merupakan makhluk yang paling luhur. Berdasarkan susunan kodratnya, manusia tidak hanya sekedar makhluk jasmaniah, tetapi juga merupakan makhluk rohaniah, yang memiliki daya cipta (kognitif), rasa (afektif), dan karsa (konatif). Aktivitas gerak manusia dapat berlangsung sebagaimana aktivitas makhluk-makhluk lainnya, misalnya: manusia dapat tergelincir jatuh, dapat tenggelam dalam air, bernafas, mencerna makanan. Aktivitas ini berlangsung begitu saja secara alamiah dan otomatis, tanpa adanya kendali dari manusia. Namun sebagai makhluk yang lebih luhur, manusia dapat melakukan kegiatan yang lebih dari makhluk-makhluk lainnya. Kegiatan tersebut merupakan kegiatan khas manusia, yang didasarkan pada kemampuan rohani manusia. Aktivitas yang dilakukan manusia tersebut berlangsung atas dasar perasaan, pemikiran, pertimbangan, pengambilan keputusan, dan selanjutnya adanya kehendak untuk melakukannya. Manusia mampu menyadari dan dapat mengendalikan tindakannya, tidak hanya sekedar berlangsung secara otomatis.

Dengan kelebihan ini, manusia diharapkan bukan sekedar sebagai obyek yang terkena hukum alam, melainkan diharapkan berfungsi sebagai subyek, yang menyadari dan menghendaki apa yang dilakukannya. Sehingga apa yang dilakukan oleh manusia, diharapkan tidak hanya sekedar efek atau reaksi terhadap rangsangan atau stimulus yang mengenai dirinya. Dalam menghadapi stimulus dari lingkungannya, diharapkan manusia (sebagai subyek) sedapat mungkin melakukan pertimbangan, pemikiran berkenaan dengan hukum alam yang berlaku, dan selanjutnya mengambil keputusan untuk bertindak sesuai dengan kehendaknya. Dan dalam menggunakan daya rohaninya tersebut, tentu saja tidak boleh ngawur, tetapi selain harus digunakan dengan benar, juga menghasilkan keputusan bertindak yang baik. Menurut Covey manusia diharapkan mampu mengembangkan daya rohaniahnya tersebut, sehingga manusia tidak menjadi korban keadaan, dan tidak bersifat reaktif terhadap keadaan, tetapi mampu berperanan sebagai subyek dalam menghadapi keadaan, dan bersifat pro-aktif, 
yang mampu merasakan, memikirkan, mempertimbangkan, dan akhirnya menghasilkan keputusan kehendak untuk menghadapi dan menangani keadaan tersebut untuk mewujudkan nilai-nilai kehidupan yang lebih baik dan lebih luhur (Covey, 1989: 66-67).

Daya pikir atau cipta manusia perlu dikembangkan, agar mampu menganalisa (mengurai) tentang hal yang dihadapi, untuk mamahami bagian-bagiannya, memahami saling keterkaitan bagian-bagian satu sama lain, memahami hubungan sebab akibat antara hal yang satu dengan lainnya; dan agar mampu mensintesakan (merangkai) bagianbagian yang ada, untuk mewujudkan satu kesatuan yang sistematis. Dengan berpikir, manusia diharapkan dapat memperoleh pencerahan /penjelasan/keterangan tentang hal yang dipikirkannya, menghasilkan pemahaman atau gambaran yang jelas dan benar tentang yang dipikirkannya tersebut. Pemahaman yang jelas dan benar inilah dapat menjadi modal untuk mengembangkan pengetahuan lebih lanjut, dan selanjutnya dapat dipakai sebagai sarana untuk mengambil keputusan tindakan menyelesaikan masalah-masalah yang dihadapi dalam kehidupannya. Orang yang bingung dalam suatu perjalanan akan terbantu oleh suatu denah yang memberikan gambaran yang jelas dan benar tentang rangkaian jalan yang akan ditempuh untuk sampai ke tujuan.

Selain daya cipta yang dapat membantu memberikan pemahaman yang jelas dan benar tentang berbagai hal dan masalah yang dihadapinya untuk diselesaikan, manusia juga memiliki kehendak atau kemauan bebas untuk dapat memilih tindakan yang mungkin dilakukannya. Sehingga selain pengetahuan, manusia juga memiliki kemauan untuk melakukan tindakan yang dipilihnya. Namun meskipun manusia memiliki kehendak bebas untuk memilih dalam bertindak, ternyata manusia tidak memilih dengan semena-mena; dan justru karena tindakan tersebut disadari, maka manusia perlu mempertanggungjawabkan tindakannya (Makmurtomo, 1989: 23-24). Dalam rangka mempertanggungjawabkan tindakannya tersebut, manusia dianugerahi daya rasa dalam hatinya, yang selalu menyertai manusia, yang menyadarkan manusia untuk selalu bertindak baik dalam hidupnya dan menghindari yang jahat. Sehingga pada saat manusia menghadapi masalah 
dan keadaan dalam hidupnya, manusia memiliki kesadaran moral untuk merasakan, memikirkan dan mempertimbangkan dalam mengambil keputusan bertindak didasarkan pada landasan bahwa manusia wajib melakukan tindakan yang baik, dan menghindari yang jahat (Bertens, 2013: 41-42).

Kesadaran hati nurani untuk melakukan yang baik dan menghindari yang jahat ini selalu menyertai manusia (conscience) dalam melakukan pertimbangan untuk mengambil keputusan bertindak. Kesadaran hati nurani yang selalu menyertai diri manusia untuk selalu memilih yang baik dan menghindari yang jahat ini merupakan kesadaran moral yang terbentuk dalam diri manusia. Namun masalahnya apakah dasar yang dapat dipakai untuk menentukan bahwa tindakan tersebut baik atau tindakan tersebut jahat. Menurut Kohlberg, kesadaran moral yang ada dalam diri manusia ini secara umum berkembang, mulai dari tingkat yang sifatnya masih kekanak-kanakan sampai ke kesadaran moral yang dewasa. Ada 3 tingkatan kesadaran moral dalam kehidupan manusia (Kohlberg, 1995: 231-234; Susilawati, 2010: 7380) yaitu:

Pertama, tingkat Pra-Adat (Pre-conventional) berlaku untuk orang-orang yang merasa bahwa aturan masyarakat berada di luar konsep diri mereka. Pada tingkatan ini, individu tidak benar-benar memahami dan berusaha menegakkan aturan masyarakat, melainkan mereka menahan diri dari perilaku yang dilarang/ditentang, karena sekedar menghindari hukuman atau untuk menerima hal positif dari aturan tersebut pada diri mereka. Aturan-aturan sosial dan sebutan baik-buruk, benar-salah, dimengerti sejauh dalam kaitan dengan akibat fisik yang dirasakan. Sesuatu dianggap baik/benar kalau secara fisik mengenakkan, dan sebaliknya dianggap buruk/salah kalau itu tidak mengenakkan. Kepatuhan pada aturan hanya karena itu mendatangkan ganjaran dan menghindarkan dirinya dari hukuman.

Kedua, tingkat Adat (Conventional) merupakan pertimbangan dan pemikiran orang-orang yang mempunyai atau menjadi bagian dalam aturan masyarakat terutama bagi mereka yang mempunyai figur otoritas. Orang berusaha menahan diri dari perilaku yang ditentang/ 
dilarang dan melakukan sesuatu yang tidak bertentangan dengan aturan untuk menghindari celaan dari orang lain dan memperoleh pujian dari orang lain, terutama dari orang-orang yang berada dalam kekuasaan. Kewajiban dirasakan sebagai segala sesuatu yang memenuhi harapan kelompok, yang dipuji kelompok, dan yang membuatnya bersatu dengan kelompok. Kelompok tidak lagi dipandang sebagai sarana bagi pemenuhan kebutuhan egonya, melainkan bernilai pada kelompokitu sendiri.

Ketiga, tingkat Pasca-Adat (Post-conventional) dimiliki orangorang yang sudah dapat membedakan konsep diri mereka dari ketentuan-ketentuan yang berlaku dalam masyarakat, dan mereka dapat menggambarkan nilai-nilai dalam kaitan dengan pemilihan prinsip untuk diri mereka. Mereka menyadari berperilaku menurut prinsip mereka sendiri ketika aturan masyarakat sejalan dengan ajaran moral yang mereka yakini. Orang berusaha memahami nilai-nilai moral dan prinsip-prinsip tingkah laku yang punya validitas serta punya penerapan lebih luas daripada hanya sekedar ditetapkan oleh yang berwenang dalam kelompok bersangkutan. Nilai-nilai dan prinsip-prinsip tersebut diterima karena dianggap benar pada dirinya sendiri, bukan karena terkait dengan ketentuan-ketentuan yang berlaku dalam kelompok terkait.

Selain tingkat-tingkat kesadaran moral tersebut di atas, juga perlu dikenal tingkat kesadaran moral otonom dan kesadaran moral heteronom. Menurut Magnis Suseno, manusia perlu mendobrak kesadaran moral heteronom dan beralih ke kesadaran moral otonom. Kesadaran moral heteronom adalah sikap orang yang memenuhi kewajiban moralnya bukan karena ia insaf bahwa kewajiban itu pantas dipenuhi, melainkan karena ia tertekan, takut berdosa, takut dikutuk Tuhan dan sebagainya. Kesadaran moral heteronom berarti bahwa orang tersebut menaati peraturan, tetapi tanpa melihat nilai atau maknanya. Ia hidup sesuai dengan tuntutan-tuntutan moral lingkungannya, bukan karena kesadaran maknanya, melainkan karena takut ditegur, takut berdosa, dan karena tak berani mengambil sikap sendiri. Heteronomi moral adalah penyimpangan dari sikap moral yang sebenarnya. Maka manu- 
sia perlu beralih ke sikap moral yang sebenarnya, yaitu sikap otonom. Kesadaran moral yang otonom berarti orang menaati kewajibannya karena ia sendiri sadar akan makna yang menjadi kewajibannya. Dalam memenuhi kewajibannya ia sebenarnya taat pada dirinya sendiri. Otonomi moral tidak berarti bahwa manusia menolak hukum yang dipasang orang lain, melainkan manusia menerimanya karena ia sendiri insaf akan perlunya hukum tersebut bagi kehidupan bersama. Manusia melakukan kewajiban bukan karena dibebankan dari luar, melainkan karena manusia sendiri menyadarinya sebagai sesuatu yang bernilai dan sebagai tanggung jawab bersama. Manusia tidak tunduk secara buta terhadap suatu hukum yang ditimpakan kepadanya, melainkan karena ia sendiri menyetujui dan menghendakinya sebagai nilai bagi kehidupan bersama (Magnis-Suseno, 1987: 44-45).

Dalam teori etika normatif dapat ditemukan berbagai pandangan tentang penilaian terhadap tindakan moral untuk menentukan tindakan sebagai tindakan yang baik yang wajib dilakukan, dan tindakan jahat yang perlu dihindari. Dalam tulisan ini akan dikenalkan beberapa pandangan saja, yang dapat dikaitkan dengan tingkat-tingkat kesadaran moral menurut pandangan Kohlberg. Pertama, yang terkait dengan tingkat kesadaran moral Pra-Adat, yaitu Hedonisme. Hedonisme bertolak dari pendirian bahwa menurut kodratnya manusia mengusahakan kenikmatan, yang dalam bahasa Yunani disebut hedone. Secara negatif usaha ini terungkap dalam sikap menghindari rasa sakit, dan secara positif terungkap dalam sikap mengejar apa saja yang dapat menimbulkan rasa nikmat. Kenikmatan benar-benar merupakan kebaikan yang paling berharga atau yang tertinggi bagi manusia, sehingga dengan demikian adalah baik bagi manusia untuk mengusahakan kenikmatan. Semakin banyak kenikmatan yang diperoleh, kian baik bagi manusia yang bersangkutan; mengenai apakah yang dinikmatinya tidaklah dipersoalkan: apakah sesuatu yang halal atau sesuatu yang haram. Orang hendaknya rela mengorbankan kenikmatan bila dapat diketahui bahwa akan membawa akibat rasa sakit lebih besar, dan hendaknya bersedia rela menderita rasa sakit sementara, agar nantinya dapat merasakan kenikmatan yang lebih besar. Orang juga perlu 
mengadakan penilaian terhadap berbagai jenis kenikmatan dan mengutamakan pada kenikmatan-kenikmatan yang dapat mengakibatkan rasa sakit yang sedikit mungkin atau bahkan sama sekali tidak mengakibatkan rasa sakit, dan selanjutnya dapat menjamin kepuasan yang berlangsung paling lama (De Vos, 1987: 161-162).

Pandangan Etika Hedonis ini cocok untuk menjadi dasar pertimbangan bagi orang yang memiliki kesadaran moral Tingkat Pra-Adat, yaitu kesadaran moral yang sifatnya masih kekanak-kanakan. Pada tingkat ini, orang merasakan bahwa lingkungan alam serta lingkungan sosial memang perlu tersedia untuk dinikmati dan menyediakan kenikmatan baginya. Anak-anak memang belum dilibatkan dan belum berperan serta dalam kehidupan masyarakat, dan tidak memiliki tugas untuk berkarya bagi kehidupan bersama, lebih bersifat konsumtif dan penikmat. Maka demi kebaikan hidupnya, anak-anak memang selayaknya hanya perlu memiliki kemampuan untuk memahami dan merasakan hal yang memberi kenikmatan untuk diterima, serta memahami dan merasakan hal yang menyakitkan untuk dihindari. Demikian pula Hedonisme ini yang merupakan pandangan moral awal kehidupan manusia, pada saat jaringan kehidupan sosial belum sedemikian kompleks, yang lebih didasarkan pada hubungan darah dan kekerabatan, serta orang masih dekat berhubungan dengan alam, yang dirasa menyediakan kekayaan alam untuk dinikmati. Sehingga selayaknya masa itu orang memunculkan pandangan hedonisme, yaitu kebaikan dinilai atas dasar kemampuan orang untuk mengusahakan kenikmatan yang sebesar-besarnya, serta menghindarkan yang menyakitkan dalam kehidupan ini.

Kedua, pandangan yang dapat dikaitkan dengan kesadaran moral Tingkat Adat, yaitu etika peraturan. Menurut Magnis Suseno, etika peraturan adalah etika-etika yang melihat hakikat moralitas dalam ketaatan terhadap sejumlah peraturan. Etika peraturan memiliki pandangan bahwa manusia yang baik adalah manusia yang dalam tindakannya selalu taat pada aturan yang ada di lingkungannya. Orang yang baik dan layak dipuji adalah orang yang tampak patuh dan taat pada aturan, menuruti perintah-perintah yang ada dalam peraturan-pera- 
turan itu; yang secara moral jahat adalah tindakan yang bertentangan dengan peraturan-peraturan tersebut. Prinsip dasar etika peraturan adalah mentaati selalu peraturan (norma-norma) yang ada dalam masyarakat. Etika peraturan menekankan pada ketaatan pada aturan, hanya mementingkan aspek lahiriah saja, yaitu tindakan lahiriah yang sesuai dengan aturan yang ada; yang terpenting adalah penampilan luar yang tampak. Sehingga kesadaran moral yang dituntut pada etika peraturan ini hanyalah menekankan pada ketaatan pada peraturan yang ada, mementingkan aspek lahiriah, yaitu tindakan yang sesuai dengan peraturan yang berlaku. Dengan demikian tidak dituntut kesadaran moral yang lebih mendalam, yang terkait dengan kesungguhan hati, maksud dan tujuan dari si pelaku. Ada dua hal penting yang tidak masuk dalam perhitungan, yaitu: hal yang mendasari berlakunya peraturan-peraturan itu, dan tanggung jawab manusia terhadap akibat-akibat tindakannya. Etika peraturan ini tentu saja dapat membentuk kesadaran moral yang dangkal (karena kebaikan hanya dilihat dari luarnya saja) dan bersifat legalistis (hanya mendasarkan pada kesesuaian tindakan dengan peraturan). Karena mengabaikan maksud tujuan, motivasi, kesadaran akan nilai yang akan diwujudkan oleh pelaku tindakan, maka etika peraturan dapat membentuk kesadaran moral yang heteronom (kesadaran untuk selalu taat pada aturan tanpa menyadari nilai yang perlu diwujudkan), dan bahkan dapat membuat orang menjadi munafik (nampaknya taat pada aturan, tetapi di baliknya dapat tersembunyi maksud jahat). Hal ini dapat juga terwujud dalam Etika Wahyu, yang sebenarnya adalah etika peraturan yang mendasarkan aturannya pada wahyu Tuhan. Meskipun isi aturannya lebih luhur (karena didasarkan pada wahyu Tuhan), namun Etika Wahyu yang lebih menekankan pada kesesuaian aspek lahiriah tindakan dengan peraturan yang berlaku dalam suatu agama, juga dapat dimungkinkan membentuk kesadaran moral yang dangkal, legalistis, heteronom, dan bahkan dapat membuat orang menjadi munafik. Segala bentuk etika peraturan ini dapat mematikan faham tanggung jawab. Yang dipentingkan bukan agar manusia hidup secara bertanggung jawab, merealisasikan nilai-nilai tertinggi kehidupan bersama, selalu 
mempertimbangkan bagaimana harus bertindak agar tujuan itu tercapai; melainkan hanya agar manusia taat pada aturan-aturan tertentu (Magnis-Suseno, 1987: 101-104). Bila dikaitkan dengan teori perkembangan kesadaran moral Kohlberg, etika peraturan ini dapat membentuk kesadaran moral orang pada Tingkat Adat (Conventional), karena orang menaati peraturan hanya didasarkan pada kesadaran moral untuk taat pada peraturan agar tindakannya dipuji oleh masyarakat, tanpa perlu mengetahui nilai yang mendasari dan termuat dalam aturan tersebut, serta tanpa perlu mempertanggungjawabkan akibat dari tindakannya.

Ketiga, pandangan yang kiranya dapat menjadi dasar pertimbangan untuk mengembangkan kesadaran moral Tingkat Pasca-Adat (Post-Conventional), yaitu Etika Nilai Material Max Scheler. Menurut Max Scheler, tindakan yang baik tidak hanya didasarkan pada sekedar memenuhi kewajiban untuk taat pada peraturan semata, melainkan juga didasarkan pada kesadaran pada kewajiban untuk mewujudkan nilai sebagai obyek yang dapat ditangkap secara a priori dari dunia nilai, bukan pada hal-hal yang bersifat empiris melalui pengalaman. Kesadaran bertindak baik juga bukan didasarkan untuk sekedar memperoleh kenikmatan pribadi, yang lebih didorong oleh egoisme naluriah manusia, melainkan didasarkan pada nilai, yang berada secara obyektif pada dunia nilai, dan diperoleh secara a priori, ditangkap dengan kesadaran hati nurani, bukan atas dasar pengalaman induktif dan empiris. Sehingga berdasar etika nilai Max Scheler, tindakan baik manusia lebih didasarkan pada kesadaran melaksanakan kewajiban demi terwujudnya nilai yang dapat ditangkap secara a priori dari dunia nilai, bukan didasarkan pada dorongan egoisme naluriah, dan juga bukan pada kewajiban semata-mata. Dalam perwujudannya di dunia inderawi ini sesuatu yang bernilai positif merupakan sesuatu yang harus atau wajib ada, dan sesuatu yang bernilai negatif merupakan sesuatu yang harus atau wajib tidak ada. Setiap kewajiban memiliki landasannya dalam nilai, tetapi nilai tidak berdasarkan pada kewajiban ideal (Scheler, 1973: 206-207; Wahana, 2004: 55-57). 


\section{ETIKA NILAI MAX SCHELER}

Berhubung Max Scheler berdasar karya besarnya yang berjudul "Etika Formalisme dan Etika Material" ("Der Formalismus in der Ethik und die materiale Wertethik") menunjukkan maksudnya untuk memberikan penilaian kritis terhadap etika formal Kant, dan selanjutnya berusaha mengatasi formalisme Kant dengan menawarkan etika nilai material, maka dalam bagian ini akan dibahas sedikit tentang etika formal Kant terlebih dahulu. Max Scheler tidak memiliki keraguan sedikit pun mengakui etika Kant sebagai jenis etika tertinggi yang pernah dihasilkan oleh pemikiran jenius di bidang filsafat. Meskipun etika Kant telah dikritik, dikoreksi dan disempurnakan dengan berhasil di sana sini oleh para filsuf yang mengikutinya, namun sama sekali belum mengena dan mempengaruhi pada dasarnya yang hakiki (Frondizi, 1971: 9495).

Menurut Kant, manusia adalah makhluk berbudi yang tidak sempurna; meskipun memiliki akal budi, namun toh memiliki nafsu-nafsu, kecenderungan emosional, selera, cinta diri, dan lain sebagainya. Di sini selalu ada kemungkinan bahwa hal-hal yang subyektif ini memegang peranan besar, sehingga perbuatan itu menjadi perbuatan sewenang-wenang. Oleh karena itu, manusia membutuhkan prinsip yang dapat memberinya pimpinan dan menjamin adanya tertib hukum di dalam dirinya sendiri, terlepas dari semua dorongan di atas. Prinsip macam ini hanyalah ditemui di dalam budi. Di sini terdapat gagasangagasan mengenai azas-azas obyektif yang menjadikan kehendak harus terjadi, terlepas dari pertimbangan untung-rugi, enak-tidak enak, dan pelbagai keinginan pribadi lainnya. Jadi yang menentukan hanyalah suatu pandangan obyektif yang dimiliki budi, yang berkata kepada manusia demikian: "Berbuatlah hanya menurut dorongan-dorongan yang diberikan budi kepadamu!"

Menurut Kant, ada dua macam imperatif, yaitu imperatif hipotetis dan imperatif kategoris. Imperatif hipotetis adalah perintah bersyarat; perintah ini mengatakan suatu tindakan yang diperlukan sebagai sarana atau syarat untuk mencapai sesuatu lain. Sedangkan imperatif kategoris adalah perintah mutlak, tanpa syarat: berlaku umum, selalu 
dan di mana-mana, sehingga bersifat universal. Imperatif kategoris ini tidak ada hubungan dengan suatu tujuan yang mau dicapai. Sifat imperatif kategoris adalah formal, artinya hanya berupa rumusan syarat-syarat yang harus dipenuhi oleh perbuatan mana pun juga agar dapat memperoleh nilai moral yang baik, terlepas dari tujuan materialnya. Kalau manusia menuruti imperatif hipotetis, ada bahaya bahwa perintah itu ditaati hanya karena kepentingan diri sendiri belaka, sehingga tersirat di dalamnya suatu dorongan egoistis. Namun tidaklah demikian halnya dengan imperatif kategoris. Imperatif kategoris tidak memerlukan suatu alasan atau syarat apa pun bagi pelaksanaannya. Imperatif kategoris inilah yang dipandang Kant sebagai azas kesusilaan yang transendental. Keharusan yang transendental dan yang amat kokoh ini mewujudkan inti segala persoalan etis. Dalam imperatif kategoris orang harus bertindak demi untuk kewajiban semata-mata. Keharusan ini bersifat mutlak, tidak memperhatikan selera suka - tidak suka, menguntungkan atau tidak menguntungkan manusia. Dengan demikian prinsip-prinsip moral tidak tergantung pada pengalaman (yang berubah-ubah), melainkan didasarkan pada suatu hukum rasional yang bersifat mutlak sebagai kewajiban tak bersyarat (imperatif kategoris). Akal budi praktis dapat menemukan prinsip-prinsip moral yang bersifat apriori (tanpa mensyaratkan datadata empiris) (Lili Tjahjadi, 1991: 49-50).

Menurut Max Scheler, prinsip a priori yang ditetapkan Kant ini dijadikan titik tolak bagi pemikirannya. Max Scheler di satu pihak memiliki keinginan untuk melanjutkan etika Kant, namun demikian Scheler juga ingin mengoreksinya dengan menegaskan bahwa Kant melakukan dua kesalahan: pertama, Kant mengacaukan antara yang a priori dengan yang formal; kedua, mengacaukan antara yang a priori dengan yang rasional. Max Scheler dapat mengakui kebenaran apriorisme Kant, yang menolak etika material sebelumnya yang didasarkan pada empirisme dan validitas induktif. Namun Scheler menemukan kesalahan pandangan Kant yang menyamakan antara yang a priori dengan yang formal, dan pandangan bahwa semua etika material itu merupakan etika tentang benda-benda dan tujuan, dan memiliki validitas 
induktif dan empiris. Kant juga keliru dalam beranggapan bahwa semua etika material adalah etika tentang keberhasilan, yang bersifat heteronom, hedonis, yang semata-mata membawa pengesahan perilaku pada egoisme naluriah, dan bukan pada moralitas yang berdasar pada kehendak murni.

Max Scheler dapat menerima bahwa Kant menolak seluruh etika yang terkait dengan benda-benda dan tujuan, namun Kant mengacaukan antara benda bernilai dengan nilai. Benda adalah obyek bernilai; dengan demikian keliru menyamakan nilai dari obyek bernilai, atau menempatkan kedua-duanya pada kedudukan yang sama. Sejauh dunia benda-benda terdiri dari barang-barang, tentu saja dapat dirusak oleh kekuatan alam atau sejarah; dan jika nilai moral kehendak manusia berdasar pada benda-benda, kehancurannya juga akan berpengaruh dan dapat terjadi pada nilai moral tersebut. Di lain pihak, obyek bernilai bersifat empiris, bersifat empiris, bernilai induktif, dan bersifat relatif, lalu bagaimana prinsip moral yang penting dan universal berasal dari kenyataan yang berubah dan tidak tetap? Tentu saja hal ini tidak mungkin. Maka Max Scheler juga menyetujui untuk ikut menolak pendasaran etika pada benda maupun tujuan yang bersifat empiris, namun menawarkan etika nilai material, yang mendasarkan etika pada nilai yang bersifat material dan sekaligus bersifat a priori dan tetap, karena ditemukannya tidak secara induktif dan tidak secara empiris (Frondizi, 1971: 95-97; Sudarminta, 2013: 148-149).

Max Scheler membantah anggapan Immanuel Kant bahwa hakikat moralitas terdiri atas kehendak untuk memenuhi kewajiban. Kewajiban bukanlah unsur primer, melainkan yang primer adalah nilai; adanya kewajiban demi nilai. Manusia wajib melakukan sesuatu demi mewujudkan nilai. Dengan demikian inti tindakan moral bukan asal memenuhi kewajiban, melainkan manusia wajib bertindak demi merealisasikan nilai-nilai. Nilai-nilai itu material dan sekaligus a priori. Material bukan dimaksudkan ada hubungannya dengan materi atau kebendaan, melainkan sebagai lawan dari kata formal, yaitu sebagai yang berisi, misalnya kesehatan, kejujuran, kekudusan. Nilai-nilai bersifat a priori, artinya nilai-nilai itu diketahui bukan atas dasar suatu 
pengalaman, melainkan diketahui mendahului pengalaman, diketahui langsung dari kesadaran terhadap nilai tersebut (Magnis-Suseno, 2006: 47-51).

Manusia perlu membedakan antara nilai-nilai (Werte, values) dengan apa yang bernilai, realitas bernilai (Guter, goods). Sebagaimana warna merah selalu muncul pada sebuah realitas berwarna merah, misalnya dinding merah, baju merah; begitu pula nilai juga selalu muncul pada suatu benda, perbuatan, atau keadaan, misalnya: makanan sehat, pola hidup sehat, pemikiran benar, tindakan benar, keadaan aman, peralatan aman. Hal-hal yang dilekati nilai tersebut, sebagai hal yang bernilai, memang bersifat a posteriori, yaitu bisa ada, dan juga bisa tidak ada; namun nilai itu sendiri adanya bersifat a priori, keberadaannya mendahului pengalaman. Sebelum terwujud dan melekat pada hal yang bernilai, nilai sudah berada pada dunia nilai. Nilai merupakan kompleks kualitas yang memiliki keselarasan dengan kecenderungan kodrat manusia, sehingga manusia cenderung tertarik untuk mengarah pada kualitas tersebut, dan kualitas tersebut dirasa layak terwujud dalam hidupnya. Dengan demikian nilai merupakan kualitas yang dapat ditangkap perasaan manusia sebagai yang memiliki daya tarik, baik sebelum terwujud maupun setelah terwujud pada yang bernilai. Nilai tidak ditemukan dengan pikiran (secara rasional), melainkan dengan suatu "perasaan intensional". Perasaan tidak dibatasi pada perasaan fisik atau emosi, melainkan merupakan keterbukaan hati dan budi dalam semua dimensinya. Secara kodrati manusia memiliki kecenderungan tertarik dan terarah mewujudkan nilai (nilai positif), dan cenderung mengelak dari yang tidak bernilai (nilai negatif) (Scheler. 1973: 12-14).

\section{ETIKA NILAI MAX SCHELER DALAM PENDIDIKAN PANCASILA}

Tulisan ini mencoba menyusun Pendidikan Pancasila, sebagai pendidikan nilai yang didasarkan pada Etika Nilai Max Scheler untuk membangun kesadaran moral mahasiswa, dalam mendukung mewujudkan nilai-nilai Pancasila. Pendidikan Nilai merupakan pengajaran 
dan bimbingan kepada peserta didik agar menyadari nilai, melalui proses pertimbangan nilai yang tepat dan melakukan pembiasaan bertindak yang konsisten dan relevan dengan nilai terkait. Tujuan Pendidikan Nilai adalah membantu peserta didik agar memahami, menyadari, dan mengalami nilai-nilai serta mampu menempatkan dan mewujudkan secara integral dalam kehidupan (Mulyana, 2011: 118-120). Dengan demikian Pendidikan Pancasila, sebagai pendidikan nilai diharapkan dapat membantu mahasiswa memahami, menyadari, dan mengalami nilai-nilai Pancasila, serta mampu mengintegrasikan dalam kehidupan mereka, sehingga dapat mewujudkan nilai-nilai tersebut dalam hidup mereka.

Tulisan ini dilakukan dalam dua tahap pemikiran: pada tahap pertama, yang menjadi objek material adalah hubungan nilai dan tindakan manusia menurut Max Scheler, dan sudut pandang sebagai obyek formal untuk membahasnya adalah dari segi etika. Setelah dihasilkan pengetahuan yang mendalam, lengkap dan menyeluruh pemikiran Max Scheler tentang nilai dan tindakan manusia, kemudian pandangan etis Max Scheler tentang hubungan nilai dan tindakan manusia tersebut akan dijadikan landasan bagi perkuliahan Pendidikan Pancasila. Menurut panggilan moralnya, manusia memiliki kewajiban untuk bertindak melakukan nilai-nilai positif dan lebih memilih nilai-nilai yang luhur, serta memiliki kewajiban menghindari nilai-nilai yang negatif dan nilai-nilai yang rendah (Scheler, 1973: 25-26).

Pada tahap kedua, Etika Nilai Max Scheler ini dicoba diterapkan sebagai landasan kegiatan perkuliahan Pendidikan Pancasila. Dengan demikian pada tahap kedua dari tulisan ini yang menjadi objek materialnya adalah perkuliahan Pendidikan Pancasila dan obyek formalnya adalah tinjauan etis menurut pandangan Etika Material Max Scheler. Tulisan tahap kedua ini, terkait dengan penerapan Etika Nilai Max Scheler sebagai dasar perkuliahan Pendidikan Pancasila untuk meningkatkan kesadaran moral mahasiswa, perlu menemukan sumber bahan yang relevan untuk dibahas dalam perkuliahan Pendidikan Pancasila, antara lain: a. Nilai sebagai kualitas yang selaras dengan kecenderungan kodrat manusia; b. Nilai-nilai Pancasila adalah nilai-nilai dasar kodrati manusia, yang juga selaras dengan kecenderungan ko- 
drat manusia; c. Nilai-nilai Pancasila yang menjiwai Perjalanan dan Perjuangan Hidup Bangsa Indonesia; d. Proklamasi yang merupakan cetusan kehendak Bangsa Indonesia yang dijiwai oleh Nilai-nilai luhur Pancasila; e. Nilai-nilai Pancasila merupakan azas bagi berdirinya dan keberadaan NKRI; f. Nilai-nilai Pancasila menjadi dasar negara, dasar untuk penataan dan pengaturan bagi berdirinya NKRI; g. Nilai-nilai Pancasila menjadi ideologi, yang layak diperjuangkan dan diwujudkan seluruh bangsa dan negara Indonesia; dan h. Perwujudan Nilainilai Pancasila dalam kehidupan bermasyarakat, berbangsa, dan bernegara.

Hasil temuan pemikiran Max Scheler tentang etika nilai material, yang telah dikomparasikan dengan etika formal Kant, dipergunakan sebagai landasan dan kerangka pikir untuk menyusun perangkat perkuliahan Pendidikan Pancasila. Kemudian penulis menerapkan perangkat perkuliahan tersebut, dalam rangka meningkatkan kesadaran moral mahasiswa, hingga mencapai Tingkat Pasca Adat (Post Conventional), yaitu kesadaran yang tidak hanya sekedar menyadari akan keuntungan dan kenikmatan yang akan diperoleh, dan juga tidak hanya sekedar memenuhi kewajiban, melainkan menyadari bahwa tindakan tersebut dapat mewujudkan nilai obyektif yang memang wajib diwujudkan selaras dengan dorongan nuraninya.

Sebelum mempromosikan nilai-nilai luhur Pancasila, mahasiswa perlu dibimbing terlebih dahulu untuk dapat menemukan nilai, sebagai kualitas yang dapat terwujud dan melekat pada yang bernilai, pada peristiwa, pada keadaan, pada tindakan, pada kepribadian. Namun bukan sembarang kualitas dapat disebut nilai, namun nilai merupakan kualitas yang selaras atau sesuai dengan kecenderungan kodrat manusia; dengan demikian dinamika kecenderungan kodrat manusia tertarik dan terarah pada nilai. Sehingga tujuan manusia secara kodrati adalah untuk mewujudkan kehidupan yang berkualitas atau yang bernilai, menjadi manusia yang berkualitas atau manusia yang bernilai. Untuk dapat menemukan dan merasakan nilai atau kualitas yang selaras dengan kodrat manusia, mahasiswa diajak merasakan kualitas yang memiliki daya tarik, yang diharapkan untuk diwujudkan berdasarkan unsur atau aspek kodrati kehidupan manusia. Misalnya, menu- 
rut unsur kejasmanian dan biologis, ternyata manusia cenderung tertarik ingin mewujudkan kekuatan, keperkasaan, dan kesehatan. Menurut unsur intelektual, ternyata manusia cenderung tertarik mewujudkan kejelasan pemahaman, kebenaran, kepandaian, kecerdasan, dan kebijaksanaan. Dan menurut aspek sosial (hubungan dengan sesama manusia), ternyata manusia cenderung untuk mewujudkan kehidupan berteman bersama yang lain (sebagai socius = teman) dalam suasana kerukunan, kerja sama, persahabatan, tolong menolong. Dan untuk mewujudkan diri menjadi manusia yang berkualitas atau bernilai, juga dibutuhkan sarana yang berkualitas atau bernilai juga. Sehingga selain ada nilai yang memang secara kodrati sesungguhnya ingin diwujudkan dalam diri manusia, ada juga nilai-nilai sarana yang perlu diusahakan untuk mendukung mewujudkan diri yang bernilai. Misalnya, manusia memerlukan makanan yang sehat, pola hidup yang sehat, dalam rangka mengusahakan menjadi manusia yang sehat. Dalam rangka mewujudkan kehidupan yang bernilai, manusia memerlukan saranasarana dan cara-cara yang bernilai, misalnya: barang yang bernilai, tindakan yang bernilai, kejadian yang bernilai, keadaan yang bernilai.

Selanjutnya, mahasiswa diajak untuk menemukan nilai-nilai yang termuat pada sila-sila Pancasila. Mahasiswa dibimbing merefleksikan untuk menemukan nilai-nilai Pancasila dalam perjalanan kehidupan bangsa Indonesia (dari aspek historis, filosofis, yuridis, dan sosiologis). Mahasiswa perlu mengeksplorasi serta mengidentifikasikan macam-macam nilai yang termuat dalam sila-sila Pancasila. Bila didasarkan pada kecenderungan kodrat sebagai manusia, ternyata nilai-nilai yang termuat pada sila-sila Pancasila adalah nilai-nilai dasar kodrati manusia, bukan sekedar sebagai nilai sarana. Selaras dengan kodrat sebagai manusia, nilai-nilai Pancasila tersebut memang wajib diwujudkan dalam kehidupan, demi mewujudkan pribadi yang berkualitas. Menurut Kaelan (2003: 15), kompetensi lulusan pendidikan Pancasila adalah seperangkat tindakan intelektual, penuh tanggung jawab sebagai seorang warga negara dalam memecahkan berbagai masalah dalam hidup bermasyarakat, berbangsa dan bernegara dengan menerapkan pemikiran yang berlandaskan nilai-nilai Pancasila.

Sebagai makhluk ciptaan Tuhan, manusia Indonesia memang 
wajib mewujudkan nilai ketuhanan dalam hidupnya, dan dapat dijabarkan dalam nilai keimanan dan nilai ketakwaan. Sebagai yang mampu menyadari akan adanya Allah, sebagai Sang Khalik, manusia Indonesia diharapkan semakin mampu mengenal secara iman akan adanya Sang Pencipta, semakin mengembangkan dan menguatkan iman. Berdasarkan iman yang dimiliki, diharapkan keimanan tersebut dapat diwujudkan dalam ketakwaan, baik hubungannya dengan Sang Pencipta, dengan sesama, maupun dengan alam ciptaan lainnya. Sebagai makhluk ciptaan yang luhur, keluhuran nilai kemanusiaan wajib untuk dijunjung tinggi, yang dapat diwujudkan dalam nilai moral, nilai keberadaban, nilai kebebasan, dan nilai budaya, yang memang mengatasi nilai-nilai yang alamiah belaka (yang berperan sebagai nilai sarana). Manusia tidak hanya sekedar sebagai objek yang terkena hukum alam, melainkan sebagai subjek otonom yang mampu memanfaatkan hukum alam serta segala hal yang di sekitarnya untuk ditata, diatur, serta dimanfaatkan sesuai dengan kehendaknya. Namun kehendak bukan sembarang kehendak, tetapi kehendak untuk mewujudkan kehidupan bernilai berdasarkan kepekaan hati nurani serta kepedulian pada lingkungan sosial maupun lingkungan alam.

Sebagai makhluk sosial (socius = teman), manusia Indonesia wajib mewujudkan nilai kekeluargaan, nilai kebersamaan, kerukunan dalam kehidupan bermasyarakat (dari lingkup lokal, regional, nasional, hingga internasional/mondial). Sebagai makhluk rohaniah (yang memiliki perasaan, kesadaran, kebebasan kehendak, dan kekuasaan), manusia Indonesia mengharapkan dalam bertindak tidak hanya sekedar sebagai robot, dalam kegiatan bersama, perlu diwujudkan hikmah kebijaksanaan yang sesuai dengan kehendak bersama (dalam bidang sosial politik) melalui permusyawaratan. Sebagai makhluk jasmaniah, manusia memiliki kebutuhan, dan perlu memperoleh sarana pemenuhannya. Dan untuk memenuhi kebutuhan hidupnya, manusia melakukan kegiatan usaha untuk memperoleh hak milik yang perlu mendapatkan perlindungan. Perlindungan terhadap hak yang dimiliki oleh setiap orang atau kelompok, serta adanya kewajiban terkait untuk memberikan perlindungan merupakan kecenderungan kodrati yang diharapkan (dalam bidang sosial ekonomi) dan perlu diusahakan untuk 
mewujudkan rasa keadilan. Itu semua merupakan kecenderungan kodrat mendasar yang ada dalam hidup manusia; manusia cenderung untuk mewujudkan nilai-nilai yang termuat dalam sila-sila Pancasila. Dan Pancasila sendiri sebenarnya memiliki gambaran manusia yang memang selaras dengan gambaran kodratnya sebagai manusia, yaitu sebagai makhluk ciptaan Tuhan, sebagai makhluk yang luhur, sebagai makhluk sosial yang perlu diwujudkan dalam kehidupan bermasyarakat, dalam kehidupan sosial politik, maupun dalam kehidupan sosial ekonomi.

Setelah menemukan dan mengenal nilai-nilai Pancasila, kemudian perlu ditemukan nilai-nilai Pancasila tersebut dalam perjuangan dan perwujudan yang telah diusahakan Bangsa Indonesia dalam perjalanan sejarahnya. Nilai-nilai ketuhanan (yang memuat nilai keimanan dan ketakwaan) perlu dicari dan ditemukan dalam tahap-tahap perjalanan sejarah dan perjuangan Bangsa Indonesia. Nilai-nilai kemanusiaan, perlu dicari dan ditemukan sebagai usaha Bangsa Indonesia dalam memperjuangkan keluhuran martabatnya sebagai manusia, untuk memiliki kebebasan mewujudkan apa yang menjadi kehendaknya, mewujudkan apa yang dicita-citakannya. Perwujudan sila ketiga, yaitu nilai persatuan, nilai kerja sama, nilai kekeluargaan yang telah terjadi dalam perjalanan dan pergaulan kehidupan bersama Bangsa Indonesia perlu dicari dan juga ditemukan. Sebenarnya nilai kerukunan, nilai kegotongroyongan, nilai kekeluargaan, dan nilai kerja sama, lebih diharapkan dan diusahakan, meskipun sering terjadi pertikaian, dan permusuhan (pada saat rasa kemanusiaan mereka diperlakukan secara tidak adil. Untuk menghindari adanya rasa ketertindasan dalam kehidupan bermasyarakat, maka perlu diusahakan dalam hidup bersama melakukan musyawarah yang dipimpin oleh hikmah kebijaksanaan dalam rangka mengambil keputusan bersama yang disepakati untuk diwujudkan dalam kehidupan bersama. Dan akhirnya dalam perjalanan sejarah Bangsa Indonesia, perlu ditemukan usaha-usaha yang dilakukan untuk mewujudkan kesejahteraan dan keadilan dalam kehidupan ekonomi mereka.

Setelah memperoleh kemerdekaan, sebagai hasil usaha untuk mewujudkan nilai kemanusiaan dan keadilan, ternyata Bangsa Indo- 
nesia tidak berhenti untuk mewujudkan nilai-nilai luhur lebih lanjut. Maka Bangsa Indonesia masih perlu berjuang lebih lanjut dengan cara hidup bernegara untuk tetap memperjuangkan dan mempertahankan nilai kemanusiaan dan nilai keadilan, selain perlu mewujudkan nilai ketuhanan, nilai kerja sama dalam kehidupan bermasyarakat, nilai kerjasama dalam kehidupan sosial politik, dan nilai kerja sama dalam kehidupan sosial ekonomi. Dengan menyadari bahwa hidup bernegara itu tidak lain merupakan cara untuk mewujudkan kehidupan yang bernilai atau berkualitas dalam berbagai aspek dan bidang kehidupan, maka Bangsa Indonesia perlu mengusahakan dengan berbagai usaha dan jalur untuk mewujudkan kehidupan yang bernilai dan berkualitas sesuai dengan nilai-nilai luhur Pancasila, sebagaimana disepakati oleh para pendiri negara. Melalui jalur pendidikan, mahasiswa perlu mengenal perwujudan nilai-nilai Pancasila dalam berbagai bidang kehidupan, serta mengenal perwujudan keadaan dan tindakan yang tidak sesuai atau menyimpang dari nilai-nilai Pancasila. Dan lebih lanjut tentu saja perlu diajak memikirkan segala permasalahan yang berkaitan dengan usaha mewujudkan nilai-nilai Pancasila dalam berbagai bidang kehidupan, terkait dengan pemahaman dan kesadaran terhadap nilai-nilai Pancasila, terkait dengan norma serta lembaga yang mendukung demi terwujudnya nilai-nilai Pancasila. Selain menemukan jalan dan cara untuk mewujudkan kehidupan yang bernilai (berdasar nilainilai luhur Pancasila), perlu juga diajak menemukan berbagai hambatan dan rintangan, serta cara untuk mengatasinya dalam usaha mewujudkan nilai-nilai luhur Pancasila,

\section{SIMPULAN}

Penilaian moral (moralitas) hanya diperuntukkan pada tindakan khas manusia, karena tindakan khas manusia bukanlah aktivitas yang berjalan secara spontan dan otomatis, melainkan tindakan yang didasari oleh kesadaran dan kehendak bebas manusia. Maka untuk memahami moralitas manusia, perlu diketahui adanya kesadaran moral, yang dipakai sebagai dasar pertimbangan dalam menentukan tindakan yang baik untuk dilakukan, dan tindakan yang jahat untuk dihindari. Melalui pendidikan moral, diharapkan dapat dikembangkan 
tingkat kesadaran moral, dari tingkat yang rendah (kesadaran yang sekedar didasari mencari kenikmatan), menuju tingkat yang menengah (kesadaran yang sekedar didasari mematuhi aturan yang berlaku dalam masyarakat), hingga sampai tingkat yang tinggi, yaitu kesadaran untuk mewujudkan nilai-nilai yang selaras dengan kecenderungan kodrat manusia.

Etika Nilai Max Scheler telah berhasil memberikan pembaharuan pendasaran bagi pertimbangan kesadaran moral, yaitu dari dasar yang sekedar menjalankan kewajiban menaati aturan yang berlaku (tanpa mempertimbangkan nilai yang perlu diwujudkan) menuju pertimbangan yang didasarkan pada kewajiban untuk mewujudkan nilainilai positif dan nilai-nilai yang lebih luhur dalam kehidupan manusia. Nilai-nilai positif dan nilai-nilai yang lebih luhur memang merupakan kualitas yang sesuai dengan kecenderungan perkembangan kodrat manusia, karena manusia memang memiliki kecenderungan untuk berkembang menjadi manusia yang bernilai atau berkualitas, serta ingin mewujudkan kehidupan yang bermartabat luhur.

Berhubung Pendidikan Pancasila, sebagai pendidikan nilai dan moral, berusaha untuk membentuk manusia Indonesia yang berkualitas dan bermartabat luhur, dengan mewujudkan nilai-nilai luhur Pancasila, maka layaklah kalau Etika Nilai Max Scheler dijadikan dasar pertimbangan untuk melaksanakan Pendidikan Pancasila, agar kesadaran moral mahasiswa tidak hanya sekedar didasari oleh kewajiban menaati aturan, melainkan didasarkan oleh kewajiban untuk mewujudkan nilai-nilai positif dan nilai-nilai luhur Pancasila.

\section{DAFTAR PUSTAKA}

Bertens, K., 2013, Etika, Penerbit Kanisius, Yogyakarta.

Covey, Stephen R., 1989, The Seven Habits of Highly Effective People, Fireside Simon \& Schuster Building Rockefeller Center, New York.

De Vos, H., 1987, Pengantar Etika, Alih bahasa: Soejono Soemargono, PT Tiara Wacana, Yogyakarta.

Frondizi, R, 1971, What is Value? An Introduction to Axiology, Opencourt 
Publishing Co, La Salle, Illinois.

Kaelan, 2003, Pendidikan Pancasila, Penerbit Paradigma, Yogyakarta.

Kohlberg, Lawrence, 1995, Tahap-tahap Perkembangan Moral. (diterjemahkan dari karya-karya penting Lawrence Kohlberg oleh John de Santo dan Agus Cremers), Kanisius, Yogyakarta.

Lili Tjahjadi, S.P., 1991, Hukum Moral (Ajaran Immanuel Kant tentang Etika dan Imperatif Kategoris, Kanisius, Yogyakarta.

Magnis-Suseno, Franz, 1987, Etika Dasar, Kanisius, Yogyakarta. , 2006, Etika Abad Keduapuluh, Kanisius, Yogyakarta.

Makmurtomo, Agus \& Soekarno, B., 1989, Etika (Filsafat Moral), Wira Sari, Jakarta.

Mulyana, R., 2011, Mengartikulasikan Pendidikan Nilai, Alfabeta, Bandung.

Poespoprodjo, W., 1986. Filsafat Moral. Bandung: CV Remadja Karya.

Scheler, Max, 1973, Formalism in Ethics and Non-formal Ethics of Values (diterjemahkan oleh Manfred S. Frings \& Roger C. Funk), Northwestern University Press, Evanston.

Sudarminta, J., 2013, Etika Umum (Kajian tentang Beberapa Masalah Pokok dan Teori Etika Normatif), Kanisius, Yogyakarta.

Susilawati, MD., dkk., 2010, Urgensi Pendidikan Moral (Suatu Upaya Membangun Komitmen Diri), Universitas Atma Jaya, Yogyakarta.

Wahana, Paulus, 2004, Nilai Etika Aksiologis Max Scheler, Penerbit Kanisius, Yogyakarta. 